\title{
Nutrition and health among migrants in the Netherlands
}

\author{
JH Brussaard*, MA van Erp-Baart, HAM Brants, KFAM Hulshof and MRH Löwik \\ TNO Nutrition and Food Research, P.O. Box 360, 3700 A Zeist, The Netherlands
}

\begin{abstract}
Objective: this paper aims to give a broad overview of published data on nutrition and health among migrants in the Netherlands, as well as data on determinants of health.

Results and conclusions: Depending on the definition, 9 to $17 \%$ of the population belongs to the group 'migrants' and this proportion is expected to grow in the coming years. Roughly $2 / 3$ of migrants are of the first generation and on average, they are younger than the Dutch population.

Relatively few data concerning the health status of migrants are available. The diet of migrants showed both positive (macronutrients) and negative (micronutrients) differences with the general Dutch diet. The risk of overweight was high among both children and adult women, and the data suggest a higher risk for Turkish and Moroccan groups than for Dutch groups. The importance of health determinants, such as smoking, alcohol use and physical and social environment, was different for migrants than for the Dutch population; however, there were also differences between ethnic groups. The limited data on morbidity for migrants suggest higher risks than for the indigenous population. The same holds for mortality data, especially for the younger age groups. In general, the data that are available suggest that the health status of migrants was less favourable than that of the indigenous population. However, there were also differences between the various groups of migrants. The lower socio-economic position of migrant groups partly explained the differences in health status. Nevertheless, a study among Turkish people indicated that their health status was lower than that of Dutch people of comparable socioeconomic status.
\end{abstract}

Keywords Migrants Diet

Health status Health determinants

\section{Introduction}

Throughout the history of the Netherlands, migrants have formed a permanent part of the Dutch population, in earlier times as well as more recently. In most cases, migrants form a heterogenous group of people coming for very different reasons from various countries, nearby as well as far away. In the first years after the second world war they mainly came from the Dutch Indies. Since the sixties they arrived as students from Surinam and the Antilles and as labour force from southern Europe and North Africa. After the independence of Surinam again many people chose to live in the Netherlands. Since the seventies, women and children from different countries came to the Netherlands for family reunion. Nowadays, the Turkish, Moroccan, Surinam and Antillean population form the larger part of migrants in the Netherlands. During the last decades also a variety of population groups have settled in the Netherlands as refugees, for example from Africa and Eastern Europe. For the Dutch Ministry of Health, Welfare and Sports, migrants are among the priority groups for health policy. Recently, more and more data on the health situation of migrants in the Netherlands have become available, but on the whole, the information is far from complete and mostly restricted to Turkish, Moroccan, Surinam and Antillean groups. The same applies to ohter countries in Europe; generally incomplete data are available that are restricted to only a part of the migrant population groups in Europe $^{1-3}$.

To identify migrants, different definitions are being used and proper description of the various population groups is a subject of discussion among researchers concerned with migrants in the Netherlands ${ }^{4}$.

First generation migrants are persons born outside the Netherlands with at least one parent also born outside the Netherlands. Second generation migrants are, according to the narrow definition, persons born in the Netherlands with both parents born outside the Netherlands. According to the broad definition, second generation migrants are persons born in the Netherlands with at least one parent born outside the Netherlands. 9\% (1 300000 
Table 1 Numbers of migrants according to country of origin; the Netherlands 1-1-1995 (Martens, 1995)

\begin{tabular}{lr}
\hline Population group & $\begin{array}{c}\text { Total number } \\
\text { (\% of total population) }\end{array}$ \\
\hline Netherlands & 15424000 \\
Turkish & $264000(1.7)$ \\
Moroccan & $219000(1.4)$ \\
Surinam & $278000(1.8)$ \\
Antillean & $93000(0.6)$ \\
\hline
\end{tabular}

persons) of the Dutch population belongs to the former category, and $17 \%$ to the latter (1-1-1995). Table 1 lists the most important migrant groups ${ }^{5}$.

The migrant population is expected to grow by more than 85\% from 1995 until the year 2015, while the expected growth of the whole population within this period is about $8 \%$.

Roughly $2 / 3$ of the migrant population groups is of the first generation. Table 2 shows the duration of stay in the Netherlands for first generation migrants, according to country of origin.

Migrants are younger than the total Dutch population: $48 \%$ of Moroccans are younger than 20 years; for Turkish, Surinam and Antillean people the figure is 42,36 and 38\% respectively ${ }^{6}$.

Table 3 shows the composition of migrant households. It can be seen from the table that the majority of people from Turkey and Morocco live as two-parent families. Among Surinam and Antillean people there are more one parent families, and among the indigenous Dutch population the proportion of singles and of childless couples is larger.

This paper will provide a broad overview of published data on nutrition, health and its determinants among migrants in the Netherlands, with emphasis on nutrition and anthropometry. Two reports form the basis of this review. An overview of nutritional studies in the Netherlands was published in 1990 by the Netherlands Nutrition Council ${ }^{7}$. Besides, an extensive review of studies on health status and determinants of health of the Dutch population and of subgroups such as migrants, was published $^{6}$. Both reports were financed by the Dutch Ministry of Health, Welfare and Sports and compiled under close supervision of leading scientists in the Netherlands.
In addition, more recent data from health and nutrition surveys carried out in the last years is included ${ }^{8-12}$. In this paper, 'migrants' refers to Surinam, Antillean, Turkish and Moroccan people in the Netherlands, unless otherwise stated.

\section{Nutrition}

In the Netherlands, nutrition surveys have been carried out for may years. First, surveys were carried out among separate population groups such as school children (Dutch as well as migrant children) or army personnel. Since the establishment of the Dutch Nutrition Surveillance system in $1986^{13}$, nutrition surveys are being carried out on a more regular basis among representative samples of the population (Dutch National Food Consumption Surveys (DNFCS) ${ }^{14-16}$ ). These general surveys form the basis for selecting risk areas (nutrients) and/or risk groups (population groups) to be studied in depth ${ }^{17,18}$. In the DNFCS, however, migrant groups are underrepresented and therefore the nutrition (and health) situation among migrants is still studied in separate surveys.

Table 4 gives an overview of nutrition surveys among migrants carried out in the Netherlands between 1978 and $1992^{7,19}$. The studies took place in the Hague, Amsterdam, Utrecht, Ede/Arnhem and Rotterdam. Recruitment for the studies was done in different ways such as through schools, participants of language class, local health organisations, and cultural centres. For nutritional assessment 24 hour recalls were used, but the level of detail was different for different studies, varying from meal pattern only to calculation of energy and macro- and micronutrients. Table 4 shows that (aspects of) nutritional status was measured in nearly all studies among migrant children; among adults this was only the case in one study among Turkish men (1992/1992, anthropometry).

Apart from the nutrition surveys there is a tradition of regular health surveys among schoolchildren in the Netherlands, where certain nutritional questions are included sometimes. In 1993/1994, nutrition was part of a health survey among children aged $0-18$ years ${ }^{9}$. Of the total sample population of 4450 children ( $51 \%$ boys, $49 \%$ girls), $88 \%$ were of Dutch origin, $3 \%$ of Surinam or Antillean origin, $4 \%$ of Turkish or Moroccan origin and 5\%

Table 2 Years in the Netherlands, according to country of origin (Martens, 1995)

\begin{tabular}{lcccc}
\hline Length of stay (years) & Turkey $(\%)$ & Morocco $(\%)$ & Surinam (\%) & The Antilles $(\%)$ \\
\hline 1 year & 4 & 3 & 2 & 5 \\
$1-2$ years & 2 & 2 & 2 & 4 \\
$2-5$ years & 11 & 13 & 7 & 18 \\
$5-10$ years & 17 & 21 & 9 & 27 \\
$10-15$ years & 17 & 23 & 18 & 15 \\
$15-20$ years & 28 & 17 & 33 & 9 \\
$20-25$ years & 18 & 12 & 19 & 9 \\
25 years & 4 & 9 & 10 & 9 \\
\hline
\end{tabular}


Table 3 Composition of migrant households in the Netherlands, according to country of origin (Martens, 1995)

\begin{tabular}{lccccc}
\hline Household type & Turkey (\%) & Morocco (\%) & Surinam (\%) & The Antilles (\%) & The Netherlands (\%) \\
\hline Single & 8 & 17 & 26 & 36 & 36 \\
Couple & 12 & 13 & 15 & 32 & 29 \\
Couple with children & 70 & 61 & 21 & 23 & 28 \\
One-parent family & 6 & 3 & 6 & 6 & 3 \\
Other & 4 & 6 & & 4 \\
\hline
\end{tabular}

of other non-Dutch origin. A written questionnaire on the consumption of meals and foods during the previous day, revealed that $93 \%$ of children of Dutch origin used breakfast on the previous schoolday, compared to $83 \%$ of Surinam/Antillean children and $81 \%$ of Turkish/Moroccan children. Compared to Dutch children, Surinam/Antillean children ate more often fish, pulses and rice or pasta and less often milk(products), sweet or savoury snacks, potatoes and meat. Children from Morocco and Turkey ate more often eggs, pulses, fish and rice or pasta and less often milk(products), potatoes, meat and soft drinks. Amounts of foods eaten were not asked in this survey and assessment of energy and nutrient intake did not take place.

The most recent nutrition surveys among migrants took place between 1996 and 1998. In 1996 and 1997, two pilot studies were carried out among Moroccan women and Surinam men ${ }^{20-22}$, respectively. They were feasibility studies for a nationwide food consumption survey among migrant population groups, which was carried out in $1998^{11,12}$. The sample in this study consisted of 91 Moroccan, 179 Turkish and 203 Dutch families with a child between 7.5 and 9.5 years old (response rate 45\%). Trained dietitians and interpreters obtained 24-h recalls from children and their mothers in their home. Other data collected were general and lifestyle characteristics and anthropometry. Iron status (hb, ferritin, saturation\%) was measured among mothers only (response rate 33\%).

The proportion of children skipping breakfast was higher among migrants than among Dutch children; 6, 8

Table 4 Nutrition surveys among migrant population groups in the Netherlands (1978-1992)*

\begin{tabular}{|c|c|c|c|c|c|c|c|c|c|c|c|}
\hline \multirow[b]{2}{*}{$\begin{array}{l}\text { Year of } \\
\text { study }\end{array}$} & \multirow[b]{2}{*}{ Origin } & \multirow[b]{2}{*}{ Age $(y)$} & \multirow[b]{2}{*}{ Sex } & \multirow[b]{2}{*}{$\mathrm{n}$} & \multirow[b]{2}{*}{$\begin{array}{c}\text { Data } \\
\text { collected }\end{array}$} & \multicolumn{6}{|c|}{ Nutritional data } \\
\hline & & & & & & Method & $\begin{array}{l}\text { Dutch } \\
\text { control } \\
\text { group }\end{array}$ & $\begin{array}{c}\text { Meal } \\
\text { pattern }\end{array}$ & $\begin{array}{l}\text { Food } \\
\text { products }\end{array}$ & $\begin{array}{c}\text { Macro } \\
\text { nutrients }\end{array}$ & $\begin{array}{c}\text { Micro } \\
\text { nutrients }\end{array}$ \\
\hline \multirow[t]{2}{*}{1978} & Surinam & 8 & $M$ & 64 & $\mathrm{~N}, \mathrm{~A}, \mathrm{~B}, \mathrm{C}$ & $24 \mathrm{~h} \mathrm{Rc}$ & $x$ & $x$ & $x$ & $x$ & $x$ \\
\hline & & 8 & $F$ & 86 & $\mathrm{~N}, \mathrm{~A}, \mathrm{~B}, \mathrm{C}$ & $24 \mathrm{~h} \mathrm{Rc}$ & $x$ & $x$ & $x$ & $x$ & $x$ \\
\hline 1981 & Sur-Hind & 8 & $\mathrm{~F}$ & 58 & $\mathrm{~N}, \mathrm{~A}$ & 24 h Rc & $x$ & $x$ & $x$ & $x$ & $x$ \\
\hline \multirow[t]{4}{*}{1981} & Sur-Hind & \pm 11 & $\mathrm{~F}$ & 19 & $\mathrm{~N}, \mathrm{~A}$ & $24 \mathrm{~h} \mathrm{Rc}$ & $x$ & $x$ & $x$ & & \\
\hline & & & M & 17 & $\mathrm{~N}, \mathrm{~A}$ & 24 h Rc & $x$ & $x$ & $x$ & & \\
\hline & Sur-Creole & \pm 11 & $F$ & 30 & $\mathrm{~N}, \mathrm{~A}$ & $24 \mathrm{~h} \mathrm{Rc}$ & $x$ & $x$ & $x$ & & \\
\hline & & & M & 8 & $\mathrm{~N}, \mathrm{~A}$ & $24 \mathrm{~h} \mathrm{Rc}$ & $x$ & $x$ & $x$ & & \\
\hline \multirow{4}{*}{$\begin{array}{l}1982 \\
1983\end{array}$} & Moroccan & \pm 11 & $\mathrm{~F}$ & 43 & $\mathrm{~N}, \mathrm{~A}$ & $24 \mathrm{~h} \mathrm{Rc}$ & $x$ & $x$ & $x$ & & \\
\hline & & & $M$ & 47 & $\mathrm{~N}, \mathrm{~A}$ & $24 \mathrm{~h} \mathrm{Rc}$ & $x$ & $x$ & $x$ & & \\
\hline & Turkish & \pm 11 & $\mathrm{~F}$ & 47 & $\mathrm{~N}, \mathrm{~A}$ & 24 h Rc & $x$ & $x$ & $x$ & & \\
\hline & & & M & 37 & $\mathrm{~N}, \mathrm{~A}$ & $24 \mathrm{~h} \mathrm{Rc}$ & $x$ & $x$ & $x$ & & \\
\hline \multirow[t]{4}{*}{1983} & Moroccan & \pm 11 & $F$ & 19 & $\mathrm{~B}$ & Vit D status & $x$ & & & & \\
\hline & & & M & 27 & B & Vit D status & $x$ & & & & \\
\hline & Turkish & \pm 11 & $F$ & 26 & $B$ & Vit D status & $x$ & & & & \\
\hline & & & $M$ & 24 & $B$ & Vit D status & $x$ & & & & \\
\hline \multirow[t]{4}{*}{1984} & Turkish & 8 & $M$ & 73 & $\mathrm{~N}, \mathrm{~A}, \mathrm{~B}, \mathrm{C}$ & 24 h Rc & $x$ & $x$ & $x$ & $x$ & $x$ \\
\hline & & & $\mathrm{F}$ & 66 & $\mathrm{~N}, \mathrm{~A}, \mathrm{~B}, \mathrm{C}$ & 24 h Rc & $x$ & $x$ & $x$ & $x$ & $x$ \\
\hline & Moroccan & 8 & $M$ & 53 & $\mathrm{~N}, \mathrm{~A}, \mathrm{~B}, \mathrm{C}$ & $24 \mathrm{~h} \mathrm{Rc}$ & $x$ & $x$ & $x$ & $x$ & $x$ \\
\hline & & & $\mathrm{F}$ & 54 & $\mathrm{~N}, \mathrm{~A}, \mathrm{~B}, \mathrm{C}$ & 24 h Rc & $x$ & $x$ & $x$ & $x$ & $x$ \\
\hline \multirow[t]{2}{*}{1984} & Turkish & - & $\mathrm{F}$ & 20 & $\mathrm{~N}$ & $\begin{array}{l}\text { Picture book + } \\
\text { interview }\end{array}$ & - & $x$ & $x$ & & \\
\hline & Moroccan & & $F$ & 20 & $\mathrm{~N}$ & $\begin{array}{l}\text { Picture book + } \\
\text { interview }\end{array}$ & - & $x$ & $x$ & & \\
\hline 1987 & Turkish & $20-47$ & M & 37 & $\mathrm{~N}$ & $2 \times 24 h \mathrm{Rc}$ & $x$ & $x$ & $x$ & $x$ & \\
\hline \multirow[t]{2}{*}{ 1991-92 } & Turkish & $18-59$ & M & 30 & $\mathrm{~N}, \mathrm{~A}$ & $2 \times 24 h \mathrm{Rc}$ & - & $x$ & $x$ & $x$ & \\
\hline & & $18-59$ & $\mathrm{~F}$ & 39 & $\mathrm{~N}, \mathrm{~A}$ & $2 \times 24 h \mathrm{Rc}$ & - & $x$ & $x$ & $x$ & \\
\hline
\end{tabular}

* Publications in Dutch; detailed references available from the authors.

$\mathrm{N}=$ food consumption data, $\mathrm{A}=$ anthropometry, $\mathrm{B}=$ biochemistry, $\mathrm{C}=$ clinical data.

$24 \mathrm{~h} \mathrm{Rc}=24$-hour recall method.

Sur $=$ Surinam.

Hind $=$ Hindostan 
and $0 \%$ of Moroccan, Turkish and Dutch boys, respectively, never ate breakfast. For girls the figure was 14, 14 and 5\% respectively.

Average total fat intake among children and Turkish and Moroccan mothers, but not among Dutch mothers was 35 energy\%. Micronutrient intake was lower among migrant mothers and children than among Dutch mothers and children.

Comparison with RDA's learned that intake of retinol (RE) was less than $80 \%$ of RDA among all groups of children; among migrant children average vitamin B1 intake was also marginal.

Among migrant women intake of retinol, vitamin B1, B2, iron and calcium, and among Dutch women intake of iron, was less than $80 \%$ of RDA.

In general, all studies so far showed that the average macronutrient intake of Surinam and mediterranean children and of Turkish and Moroccan women was more in line with the Dutch Guidelines for a healthy diet than the conventional Dutch diet. Their food contained less fat, particularly saturated fat, more carbohydrates, and the ratio between polysaccharides and mono/disaccharides was more favourable. However, mean intakes of vitamins and minerals were lower than among Dutch reference groups and more often below the RDA (particularly calcium, iron, and one or more B vitamins). Although there were some differences between studies, a lower consumption of milk and milk products, the use of leaner meats, more frequent use of oil instead of margarine and butter and less frequent consumption of soft drinks, biscuits and sweets contributed to these findings.

Possible changes in consumption patterns of migrant children in 1998 as compared to $1984^{23}$ are being studied at this moment.

Insofar as biochemical and clinical data are available for children, these were in line with the food consumption data.

The low intake of iron among Moroccan and Turkish women was confirmed by a low iron status; the prevalence of low iron status was the highest among Turkish women. Also in line with the dietary data, total serum cholesterol levels were on average lower among Turkish and Moroccan women than among Dutch women.

\section{Anthropometry}

In the surveys available, anthropometric data are mostly obtained by measuring weight, height and one or more skinfold(s) or arm circumference. No reference data for migrant children in the Netherlands are available yet, so data for migrant children are usually compared to data from Dutch children from the same or comparable surveys, or with other published reference data.

From health surveys among children aged 0-18 years in 1992/93 and 1993/94 it appeared that average body mass index among Turkish and Moroccan children was higher than among Dutch children ${ }^{8,9}$. A body mass index above the P97 of the reference values of RollandCachera ${ }^{24}$ was prevalent among $16 \%$ of Turkish and Moroccan children aged 4-15 years as compared to 8\% among Dutch children of the same age-groups (data 1992/1993). However, it should be noted that socioeconomic status was lower among migrant groups.

Weight per $100 \mathrm{~cm}$ and arm circumference per $100 \mathrm{~cm}$ among Moroccan, Turkish and Dutch children in 1998 were higher than among comparable groups in 1984. The percentage increase in mean arm circumference per $100 \mathrm{~cm}$ was slightly greater among migrant children than among Dutch children ${ }^{11,23}$.

Furthermore, from the health survey among children it appeared that migrant children took part in less sports activities than Dutch children (1992/1993). A lower level of physical activity was also reported for Turkish and Mororoccan girls and women in comparison with Dutch girls and women ${ }^{6}$.

The above findings suggest that both migrant and Dutch children are at risk of overweight, with a higher risk for migrant children and women.

Mean body mass index among Moroccan, Turkish and Dutch women ( $\mathrm{n}=91,180$ and 202; mean age 35, 33 and 38 years) was $30.8,28.8$ and $25.7 \mathrm{~kg} / \mathrm{m}^{2}$, respectively; mean waist circumference was 94,85 and $83 \mathrm{~cm}$, respectively ${ }^{11}$. The prevalence of overweight (according to BMI or waist circumference) was high among all groups of mothers. Severe overweight (waist circumference more than $88 \mathrm{~cm}$ ) was prevalent among more than $25 \%$ of Turkish and Dutch mothers and more than $50 \%$ of Moroccan mothers.

\section{Factors related to health and nutrition}

In 1991, a health interview was carried out among Turkish inhabitants of the Netherlands ${ }^{25}$. Recently, a similar interview was held among Moroccan people in the Netherlands, but the results have not been published yet. Apart from that, a variety of subjects has been studied among various samples of the Dutch migrant population. These have been thoroughly reviewed ${ }^{6}$. An extensive rewiew of all studies on health, morbidity and mortality is beyond the scope of this paper. Therefore, in this and the following sections only the most relevant conclusions will be given.

Alcohol intake is an important aspect of lifestyle. However, it is well known that it is difficult to reliably assess alcohol intake and probably the more so among population groups with religious taboos on alcohol intake. Reported alcohol use was lower among people from Turkey and Morocco in comparison with the Dutch population. However, underreporting may play a role here. Relatively many alcoholproblems were identified among Surinam-Hindostans in the Hague. 
Smoking was less common among Surinam, Moroccan and Turkish youth than among Dutch youth. However, a health survey among Turkish men revealed that among the 24-44 year olds the proportion smokers was 70\%, against 43 among Dutch men, while the number of cigarettes smoked was also higher among Turkish men. The proportion of smokers among Turkish women is slightly lower than among Dutch women; among Surinam and Moroccan women the proportion of smokers is clearly lower.

Migrants were overrepresented among drugusers. Drugproblems were more common among migrants, while alcohol problems were more common among the indigenous population.

The physical and social environment also influence the health situation of the migrant population. The majority of migrants live in the big cities in the west of the country, and the quality of their housing is often worse than that of other people.

The lower socio-economic position of migrant groups partly explains the differences in their health situation. However, the health status of Turkish people appeared to be lower than that of Dutch people of comparable socio-economic status.

Turkish and Moroccan families fall in the lower income categories, because of their educational and professional level. The educational level of Antilleans is equal to that of the Dutch population in general, and Surinam families are in the middle categories. However, the unemployment level amon all migrant groups is higher then among the rest of the population.

\section{Morbidity}

Morbidity data available for migrants are far from complete and those that are available are varied ${ }^{6}$.

For children the following data are available. Among Moroccan children (0-19 years old), the incidence of type I diabetes was 1.6 that for Dutch children.

Dental health was different for the different ethnic groups: one third of 5-year old Moroccan and Turkish children had a healthy set of teeth, compared to almost two third of Surinam, Antillean and Dutch children. Migrant children used fluoride less frequently and visited their dentist less frequently than Dutch children.

Enuresis nocturna was more prevalent among Turkish and Moroccan children of 5 years and older (1992/1993); however, this was no longer the case among children of 7 years and older.

A survey among infants and schoolchildren showed a lower prevalence of asthmatic complaints among migrant children than among Dutch children. For example, among Dutch schoolchildren the prevalence of recent asthma was $12.7 \%$, while this was $11.8,9.4$ and $6.2 \%$ for Surinam, North African and Turkish children, respectively ${ }^{10}$.
For adults it was found that chronic diseases were more prevalent among Turkish men and women than among Dutch men and women $(+50 \%$ and $+15 \%$, respectively). For other migrant groups no such data are available.

Insulin resistance and insulin resistant diabetes (type II) was more prevalent among Surinam Hindostans. The age of onset was lower and complications are possibly more serious.

Migrant groups, tended to have more health complaints as compared with the Dutch population and people from Turkey more than those from Surinam or the Antilles (no recent data on Moroccan people).

Hospitalisation because of psychological problems was higher among some, but not all, migrant groups than among the Dutch population. However, the extent to which this represents a real difference in psychological problems is not clear.

\section{Mortality}

An analysis of mortality data on migrants is difficult to assess, e.g. because there is no complete insight into the percentage return to the country of origin among older migrants. As migration is never a random process, one should also be aware of selection bias. The data that have been analysed so far indicate that mortality was higher among most of the migrant groups, especially in the younger age groups. An exception was the (standardised) mortality among adult Antilleans, which was lower than among the indigenous Dutch population.

Perinatal mortality among migrants was 1.5-2 higher than among the rest of the population. Among people from Surinam and the Antilles this can be explained by premature birth; among people from Morocco and Turkey it can be partly explained by teenage and multiple pregnancies.

The increased mortality among Turkish and Moroccan children and adolescents can be explained by inherited and infectious diseases, accidents and other external causes. Infectious diseases and accidents often take place while families were abroad, e.g. visiting the country of origin during holidays.

Few data are available on mortality among people from Surinam and the Antilles. Data from the Hague suggest an increased mortality from diabetes among Surinam Hindostans.

\section{Summary and conclusions}

Relatively few data concerning the health status of migrants are available; not all migrant population groups, nor all aspects of health have been studied. Therefore, an important conclusion might be that more comprehensive research concerning health and nutrition among migrants in the Netherlands is needed. Furthermore, it is not possible to give a complete picture of the nutrition and 
health status among migrants in the Netherlands. In general, the data that are available suggest that the health status of migrants is worse than that of the indigenous population. However, there are also differences between the various groups of migrants. More specifically, the following conclusions can be drawn.

Nutrition surveys mostly concerned children and/or women. The results showed that macronutrient intake among migrants was often more in line with the guidelines for a healthy diet than that among the Dutch population. Micronutrient intake was lower among migrants than among the Dutch population. Breakfast was used less frequently by migrants than by the indigenous population.

Data on nutrient intake as well as iron status indicated that women of childbearing age were at risk of marginal irons status, and migrant women more than Dutch women.

Children were at risk of overweight and the data suggest a higher risk for migrant children.

Severe overweight (waist circumference more than $88 \mathrm{~cm}$ ) was prevalent among more than $25 \%$ of Turkish and Dutch women and more than $50 \%$ of Moroccan women.

Health determinants, such as smoking, alcohol use and physical and social environment were different for migrants than for the Dutch population; however, there were important differences between migrant groups.

The limited data on morbidity for migrants suggest higher risks than for the indigenous population. The same holds for mortality data, especially for the younger age groups.

\section{References}

1 Wandel M. Nutrition-related diseases and dietary change among third world immigrants in Northern Europe. Nutrition and Health 1993; 9: 117-33.

2 Rovillé-Sausse F. Évolution en 20 ans de la corpulence des enfants de 0 à 4 ans issus de l'immigration maghrébine. Rev . Epidém. Et. Santé. Publ. 1999; 47: 37-44.

3 Proceedings from The first European Workshop on human migration and nutrition. Scand. J. Nutr. 1996; 40(Supplement no 31): S1-128.

4 Bruynzeels M. Het meten van etnische herkomst. Report of a workshop (in Dutch). ZorgOnderzoek Nederland en Nederlandse Organisatie voor Wetenschappelijk Onderzoek. Den Haag, 1999.

5 Martens EP. Minderheden in beeld, kerncijfers 1995 (Onderzoek in opdracht van de directie Coördinatie minderhedenbeleid van het Ministerie van Binnenlandse zaken). ISEO, 1995.

6 Maas IAM, Gijsen R, Lobbezoo IE, Poos MJJC. Volksgezondheid Toekomst Verkenning 1997. I. De gezondheidstoestand: een actualisering. Van Wersch SFM, Uniken Venema HP, Schulpten TWJ. De gezondheidstoestand van allochtonen. In: Mackenbach JP, Verkleij H. II. Gezondheidsverschillen. Elsevier/De Tijdstroom, Maarssen, 1997. (In Dutch. English summary available as Ruwaard D and Kramers PGN. Public Health Status and Forecasts).
7 Ten Hoor F, et al., eds. Nutrition, Food and Health in the Netherlands. Summary of the Nutrition Report 1990. Netherlands Nutrition Council, the Hague, 1990.

8 Spee-van der Wekke J, Meulmeester JF, Radder JJ, VerlooveVanhorick SP, Schalk-Van der Weide Y. Peilingen in de jeugdgezondheidszorg: PGO-peiling 1992/1993. Rapport nr. 94.091. TNO Preventie en Gezondheid, 1994.

9 Brugman E, Meulmeester JF, Spee-van der Wekke A, Beuker RJ, Radder JJ. Peilingen in de jeugdgezondheidszorg: PGOpeiling 1993/1994. Rapport nr. 95.061. TNO Preventie en Gezondheid, 1995.

10 Van der Wal MF. Ethnic differences in bealth in children. Thesis. Utrecht: 1997.

11 Brussaard JH, Brants HAM, Van Erp-Baart AMJ, Kistemaker C. De voeding bij allochtone bevolkingsgroepen. Deel 3. Voedselconsumptie en voedingstoestand bij Turkse, Marokkaanse en Nederlandse 8-jarigen en hun moeders. TNOrapport V99.855, Zeist, 1999.

12 Brussaard JH, Brants HAM, Van Erp-Baart AMJ, Hulshof KFAM, Löwik MRH. Diet and nutritional status among 8-year old Turkish, Moroccan and Dutch children and their mothers. Scand. J. Nutr. 1999; 43(2S): 82 S Abstract.

13 Voedingsraad. Mogelijkheden tot het opzetten van een voedingspeilingssysteem in Nederland. Voeding 1987; 48 $35-43$.

14 Löwik MRH, Brussaard JH, Hulshof KFAM, Kistemaker C, Schaafsma G, Ockhuizen T, Hermus RJJ. Adequacy of the diet in the Netherlands in 1987-1988 (Dutch Nutrition Surveillance System). Int. J. Food Sci. Nutr. 1994; 45(Suppl. 1): $\$ 1-62$.

15 Löwik MRH, Hulshof KFAM, van der Heijden LJM, Brussaard JH, Burema J, Kistemaker C, de Vries PJF. Changes in the diet in the Netherlands: $1987-88$ to 1992. Int. J. Food Sci. Nutr. 1998; 49(Supplement 1): S1-64.

16 Anonymous. Zo eet Nederland 1998. Resultaten van de voedselconsumptiepeiling 1998. Voedingscentrum, den Haag, 1998.

17 Löwik MRH, Hermus RJJ. The Dutch Nutrition Surveillance System. Food Policy 1988; 13: 359-65.

18 Brussaard JH, Brants HAM, Löwik MRH. Nutritional status among adults with special reference to micronutrients (Dutch Nutrition Surveillance System), Eur. J. Clin. Nutr 1997; 51(Suppl 3): S1-66.

19 Brussaard JH, van Erp-Baart AMJ, Westenbrink S, Hulshof KFAM, den Breeijen JH. De voeding bij allochtone bevolkingsgroepen. Deel 1. Pilotstudie naar voedselconsumptie bij volwassen Marokkaanse vrouwen. TNO rapport V97.453, Zeist, 1997.

20 Brussaard JH, Van Erp-Baart AMJ, Westenbrink S, Hulshof KFAM, Den Breeijen JH. De voeding bij allochtone bevolkingsgroepen. Deel 1. Pilotstudie naar voedselconsumptie bij volwassen Marokkaanse vrouwen. TNO-rapport V97.453, Zeist, 1997.

21 Van Erp-Baart AMJ, Westenbrink S, Hulshof KFAM, BoekemaBakker N. De voeding bij allochtone bevolkingsgroepen. Deel 2. Pilotstudie naar voedselconsumptie bij volwassen Surinaamse mannen. TNO-rapport V97.1070, Zeist, 1998.

22 Van Erp-Baart AMJ, Westenbrink S, Hulshof KFAM, Brussaard $\mathrm{JH}$. Assessment of dietary intake among Moroccan women and Surinam men. Ethnicity and Health, in press.

23 Meulmeester JF. Voedingsonderzoek bij Turkse en Marokkaanse kinderen in Nederland. Thesis. Amsterdam: 1988.

24 Rolland-Cachera MF, Sempé M, Guillod-Bataille M, Patois E, Péquinot-Guggenbuhl F, Fautrad V. Adiposity indices in children. Am. J. Clin. Nutr. 1982; 36: 178-84.

25 Central Bureau of Statistics. De gezondheidsenquete Turkse ingezetenen in Nederland 1989/1990. Sdu Uitgevers, den Haag, 1991. 